\title{
船首船橋船の打ち込み海水挙動に関する模型実験
}

\section{定兼 廣行*・金 皓承** \\ Model Experiment on Flow Behavior of Shipped Water for a Fore Bridge Ship}

\author{
Hiroyuki SADAKANE and Chol-Seong KIM
}

\begin{abstract}
The wheelhouse front glass of a fore-bridge-ship had been destroyed by the shipping of water in rough sea, and the ship had fallen into uncontrollable conditions for ship handling. The above destruction was an unbelievable fact for us because the front glass was in a very high position (about $20 \mathrm{~m}$ ) above the water surface.

In this study, we carried out the water tank experiment using a model ship and regular waves, and observed the appearance of the shipping of water and the behavior of the shipped water flow by using video-cameras. And also the speed of the flow destroyed the front glass was tried to analyze from video-pictures. The obtained results are as follows:

(1) The water shipped from the fore end and both sides of the bow was concentrated on the centerline of the deck and flew toward the bridge like a rushing stream with ample quantity.

(2) After collided with the bridge, the rushing stream ran up forcefully on the front face of the bridge. In this case, this flow did not flow along the vertical slope of the bridge wall but ran up with a rather lower angle than the above slope. And finally the stream crashed directly into the front glass part.

(3) Such rushing flow clearly occurred in the condition to be the wave steepness $H / \lambda$ over about $1 / 10$ and the wave length/ship length ratio $\lambda / L$ over about 1.0 .

(4) According to simple analyzing method, the flow speed at the front glass height was $3 \sim 3.5$ times as fast as the velocity of the surface wave elevation.
\end{abstract}

\section{1.はじめに}

船首船橋船 (Ro-Ro船) が荒天向波中を微速航行中、操舵室前面空ガラスに達する打ち込み海水によって 前面ガラスが破損し、この海水の操舵室への打ち込みによって室内の電気系統にマヒが生じ、船が操縦不 能になるといら事故が発生した。浮遊状態に入った船体は激しく横摇れし、操舵室内の打ち込み海水の流 動、積み荷の転倒などの二次的な被害をもたらした。この船の船首ブルワーク上面の高さは水面上約 $15 \mathrm{~m} ゙$ あり、また空ガラスは約 $20 \mathrm{~m}$ の高さにあるので、この操舵室への大量の海水打ち込みはやや想像しがたい。 そこで、本研究では空ガラスに破損を引き起こした海水打ち込みがじのような経過を経て発生したのかを 調べるために模型実験を行い、海水打ち込みの様子、甲板上打ち込み海水の流動模様及び操舵室空ガラス に達する高速水流の性質などについて調査した。

\section{2. 水槽実験}

* 正 会 員 神戸商船大学（产658-0022 神戸市東灘区深江南町5-1-1）

**学生会員＼cjkstart神戸商船大学大学院（率658-0022＼cjkstart神戸市東灘区深江南町5-1-1） 
表 1 船体主要目

\begin{tabular}{|lr|r|c|}
\hline \multicolumn{2}{|r|}{ 要目 } & \multicolumn{1}{c|}{ 実船 } & 模率 $(1 / 118.5)$ \\
\hline$L_{\mathrm{PP}}$ & $(\mathrm{m})$ & 142.20 & 1.200 \\
\hline $\mathrm{B}$ & $(\mathrm{m})$ & 24.00 & 0.203 \\
\hline $\mathrm{D}$ (上甲板 $)$ & $(\mathrm{m})$ & 15.15 & 0.128 \\
\hline $\mathrm{d}_{\mathrm{f}}$ & $(\mathrm{m})$ & 4.55 & 0.038 \\
\hline $\mathrm{d}_{\mathrm{a}}$ & $(\mathrm{m})$ & 6.70 & 0.057 \\
\hline$\Delta$ & (tonf) & $10,700.0$ & 0.0064 \\
\hline $\mathrm{KG}$ & (m) & 9.40 & 0.079 \\
\hline
\end{tabular}

実験は神戸商船大学浅長水槽 $(60 \times 6 \times 1.5 \mathrm{~m})$ の 水深 $1.0 \mathrm{~m}$ において行った。使用した模型船 (縮率： 1/118.5)の主要目を表 1 に示す。実験状態はほぼ満 載状態であった。事故当時の船首喫水は $4.55 \mathrm{~m}$ であ り、また図 1 に示すように船首ブルワーク上面まで

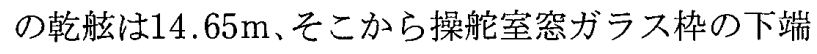
までの高さは約 $5 \mathrm{~m}$ であるから空ガラスは海面上約 $20 \mathrm{~m}$ 高さにあったことになる。

水槽実験は模型船を無線操縦により正面向波中で 自由航走させ、船首部上方及び側面よりビデオカメ ラにより甲板上海水打ち込み及び打ち込み海水の挙 動を撮影した。船速は荒天中の船速低下を考慮に入 れ、実船で約 $5.0 \mathrm{knots}(F n=0.075)$ に相当する船速 を中心に必要に応じて 1 knot增減させた。波は規則 波で、波長船長比 $\lambda / L=0.8 \sim 1.5$ 、また波高波長比 $H / \lambda=1 / 30 \sim 1 / 8$ を実験範团とした。

\section{3. 実験観察}

\section{1 甲板上打ち込み水の挙動}

打ち込み水の様子及び甲板上打ち込み水の流動模 様はビデオカメラ (30コマ/秒, シャッター速度：1/ 500秒)で撮影し、これの録画を再生した静止画像か ら観察を行った。

写真 1 (a) (c) は $\lambda / L=1.2, H / \lambda=1 / 15, F n=$ 0.075 の実験状態であり、船首部上方から撮って再生 した連続写真の一例である。連続写真から観察され る打ち込み水の様子及び流動模様は以下の通りである。まず、船体運動によって船首の前方及び側面で発 生した水の壁が縦摇れの船首下げが最大になった直後に船首の最も先端付近から破れ、写真 1 (a) のよう に船長方向の速度を持つ水が一気に甲板上に打ち込む。一方、その直後写真 1 (b) のように船首の雨舴から も甲板上中心線上に向から横方向成分の速度をむつ打ち込み水が流れ込んでくる。結局、これらを合成し

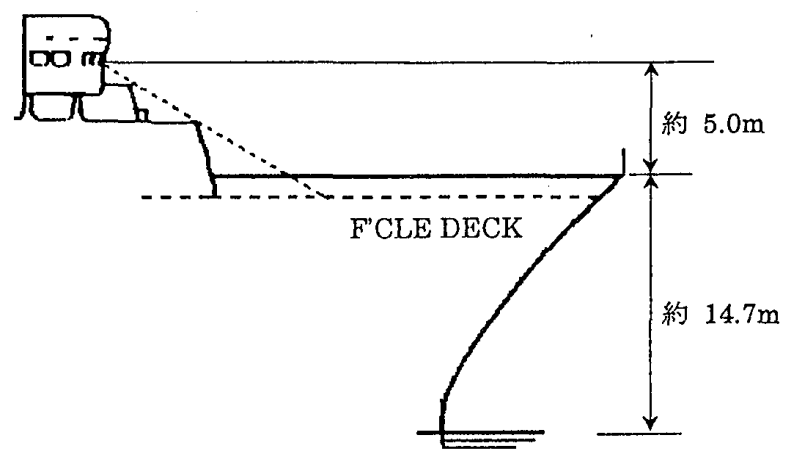

図 1 水面上船首部の形状

(a)

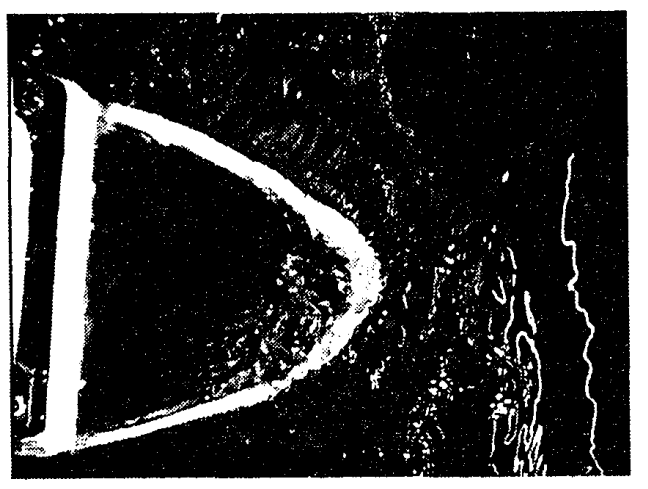

(b)

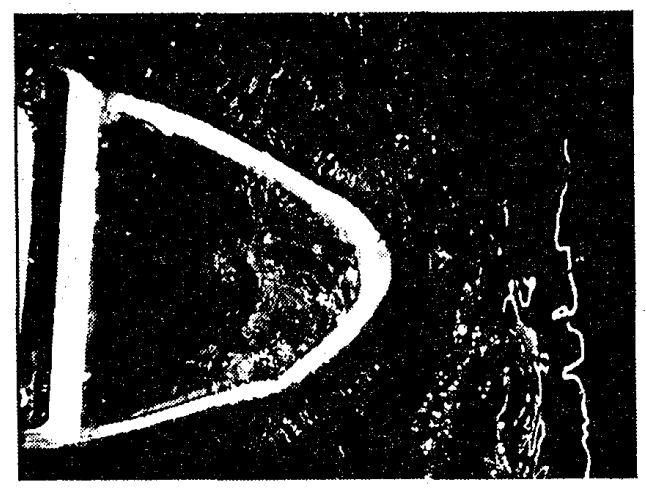

(c)

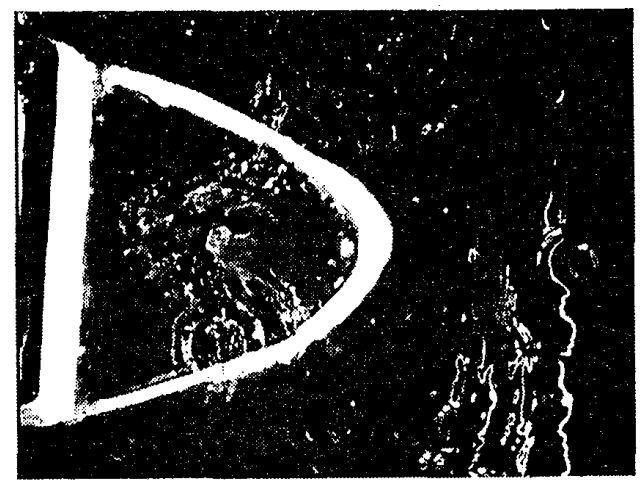

写真 1 甲板上打ち込み水の収束流動の模様

$(\lambda / L=1.2, H / \lambda=1 / 15, F n=0.075)$ 
た流れは写真 1 (c)のように甲板上船体中心線付近 で収束現象を生じ、高い水位と速い速度になった水 塊は甲板上中心線に沿って船尾方向に流れ、船橋前 端面の下部に衝突することが観察される。

次に波岨度のみを $H / \lambda=1 / 10$ に変化させた場合 も打ち込み水の流入過程は全般的に写真 1 (a)、 (b)の様子とほぼ同じようである。しかし波岨度が 大きくなるにしたがって、船首先端付近から甲板上 に流机込む打ち込み水の量が多くなると共に船首両 䑪からの打ち込みも一層激しくなって、写真 2 のよ うに船体中心線付近で水の収束がもっと明瞭とな る。

\section{2 高速上昇水流}

ここでは操舵室前面空ガラスに破損を引き起こし た直接原因である高速上昇水流の発生過程について 調べる。

写真 3 は、 $\lambda / L=1.3, H / \lambda=1 / 10, F n=0.075$ の場合におけ扮体側面から撮った連続写真の一つ であり、操舵室前面空ガラスを直撃する高速水流の 典型的な例である。この場合、前の写真 2 のように 甲板上船体中心線付近で収束した水が高い水位にな って船橋前端面の下部に衝突し、次いで船橋楼前端 面に沿って上層甲板の凹みを飛び越えて駆け上が る。この水流はちょうど図 1 中に破線で示す経路で 駆け上がっている。このようにごく勢いよく、超多 量の水が上昇する場合は、この水流は空ガラスを直 撃する衝撃水流となる。

しかし、操舵室前面ガラスに達する水流は発生す るが、写真 $4(\lambda / L=0.8, H / \lambda=1 / 10, F n=0.075)$ のように上昇水流の量が少なく、また速度が小さい ため船橋最前端の壁面に沿う上昇流が主流となり、 空ガラスに当たる水量は少ない場合もある。

以上の実験観察を要約すると、高速水流の上昇仰 角は必ずしも船橋最前端面の勾配に一致せず、むし ろ多量で高速の水流が船橋楼前端面を駆け昇る時に は図 1 に示した破線のように船橋楼甲板等の前端部 を結んだ角度で上昇し、空ガラスに直撃するようで ある。

\section{4. 空ガラス高さにおける上昇流速の解析とそ の結果}

操舵室前面空ガラスに破損を起こした水流の衝撃 圧力は水流の衝突直前の速度が重要な因子の一つで ある。そこで前章に示したような記録映像を基に操 舵室付近高さにおける水流の上昇速度の解析を試み る。

\section{1 解析方法}

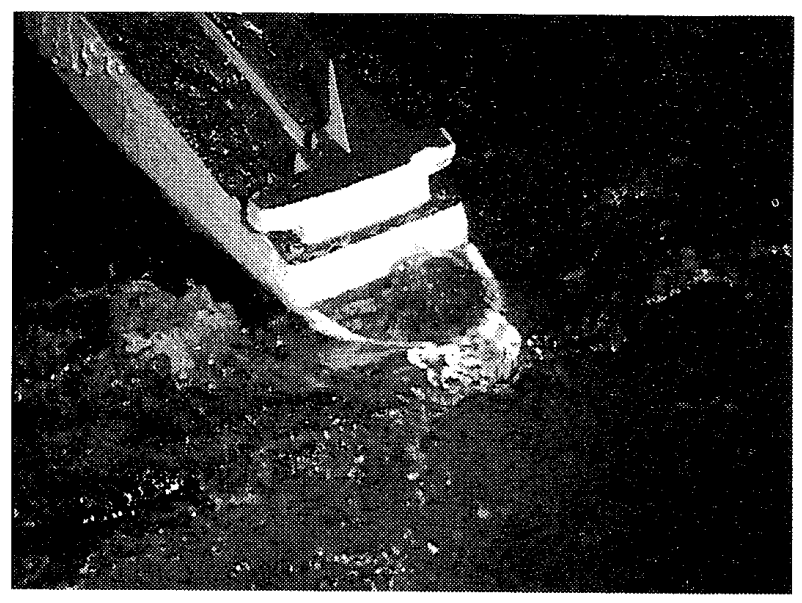

写真 2 斜め上方から見た甲板上打ち込み水の収束 流動模様

$$
(\lambda / L=1.2, H / \lambda=1 / 10, F n=0.075)
$$

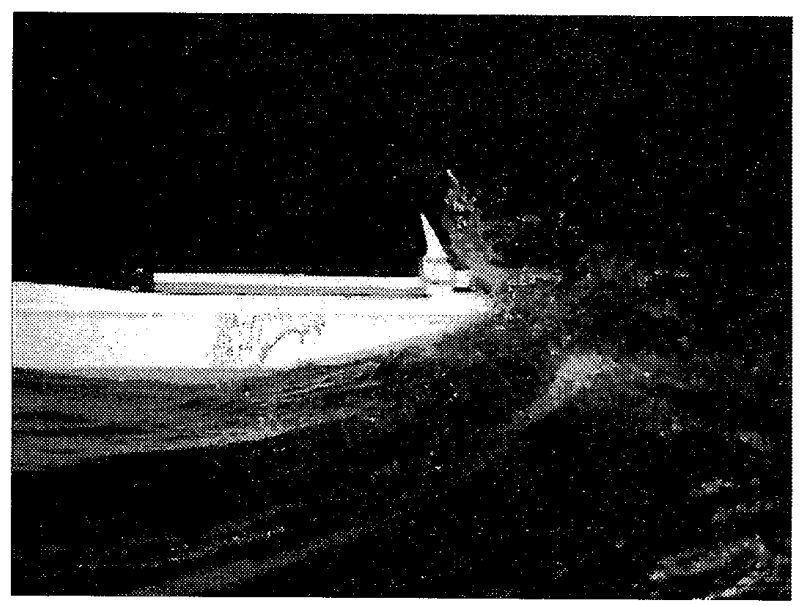

写真 3 悹ガラスに衝撃を与える高速上昇水流 $(\lambda / L=1.3, H / \lambda=1 / 10, F n=0.075)$

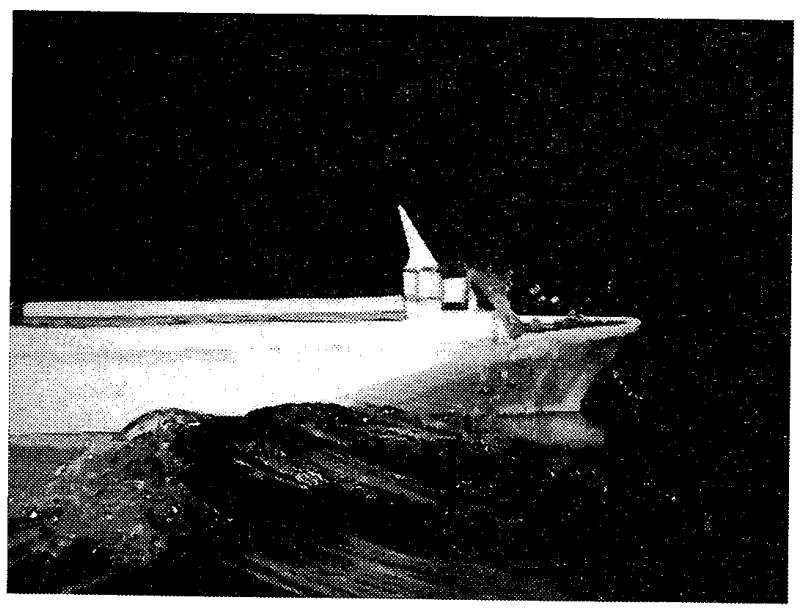

写真 4 衝撃が少ない場合の上昇水流 $(\lambda / L=0.8, H / \lambda=1 / 10, F n=0.075)$ 
ここではごく簡単に次のような考え方に従って解 析する。つまり、ある基準高さの上昇水流が有する 運動エネルギーは、水流の上昇と共に運動エネルギ 一を消費してやがて勢いを失って静止し、次いで落 下に転じる。これは運動エネルギーが位置エネルギ 一に置き換わった瞬問である。今実験の場合も上記 の様子が比較的明瞭に現れており、船橋前面を駆け 昇る上昇水流は、写真 5 に示すように、左右に分か れてやがて上方への勢いを失う。

従って、基準高さを操舵室前面空ガラス枠の下部 において、そこから水流が達した高さをんとすると、 基準高さに沶ける水流速度 $V_{\text {世 }}$ は次式によって解析 される。

$$
V_{u}=\sqrt{2 g h}
$$

ただし、gは重力加速度で、hは水流最上部の高さで あり、そこから飛び散った飛沫は対象としない。こ のhの高さは記録映像中に写っているレーダマスト の高さ (既知)を基に比例計算により算出した。この $V_{u}$ は垂直方向の流速であるので図 1 の破線で示す 方向の流速より小さくなるが、上昇流速を代表する と仮に考えることができるであろう。

\section{2 解析結果}

先ず $\lambda / L=1.2$ に固定して波岨度を変化させて (1)式の水流上昇速度を解析したものを図 2 に示す。 縦軸は上昇速度を入射波の最大上昇速度で除して無 次元化した。 $H / \lambda=1 / 30$ では船首の乾船が比較的 高いため甲板上に打ち込みが発生しなかった。また $H / \lambda=1 / 15$ の場合は甲板上に打ち込んだ水が船体 中心線である程度収束され、船橋楼前端面の下部に 衝突するが、空ガラスに達する衝撃水流にならなか った。しかし、 $H / \lambda=1 / 10$ 程度になると、突然衝撃 水流になると共に水流上界速度も一挙に大きくなっ た。これ以上の波岨度では上昇速度の無次元值は少 しずつ減少する傾向が現れたが、水流上昇速度は入 射波の最大上昇速度に比べて約3.0～3.5倍になっ た。

次に $H / \lambda \fallingdotseq 1 / 10$ に固定して船速及び波高船長比 を変化させて(1)式の水流上昇速度を見たものを図 3 に示す。縦軸は図 2 と同様に無次元值である。波長 の短い $\lambda / L=0.8$ 場合は水流上昇速度が小さく、 特に $F n=0.060$ の場合は船橋空ガラスの高さまで至 る水流は発生しなかった。しかし波長と船長が等し い $\lambda / L=1.0$ では衝撃水流が発生し、その上昇速度 は波面上昇速度の $3.0 \sim 3.5$ 倍となった。 $\lambda / L=$ $1.0 \sim 1.5$ の間で無次元上昇速度の差違は少なく、や はり3.0〜3.5倍になった。

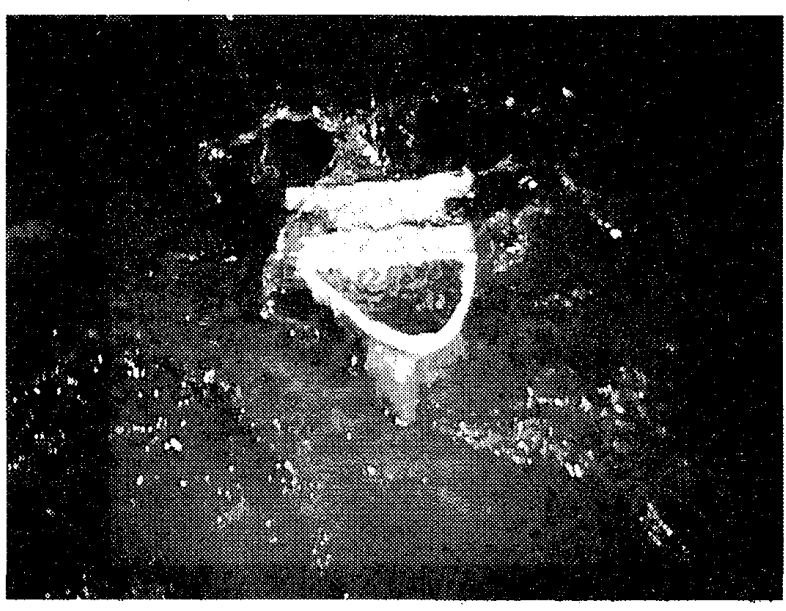

写真 5 高速上昇水流の分岐の模様 $v_{w} / \zeta \omega$

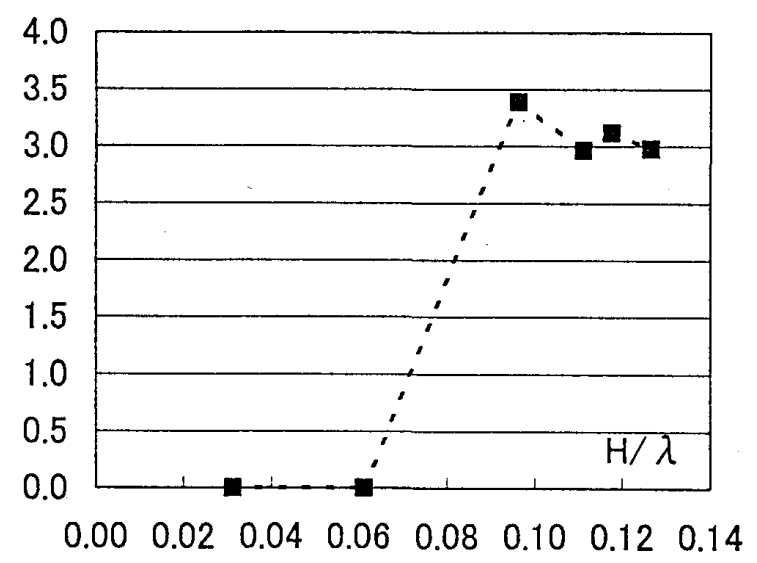

図 2 波岨度による空ガラス高さで無次元水流上昇 速度の変化

$(\lambda / L=1.2, F n=0.075)$

$v_{w} / \zeta \omega$

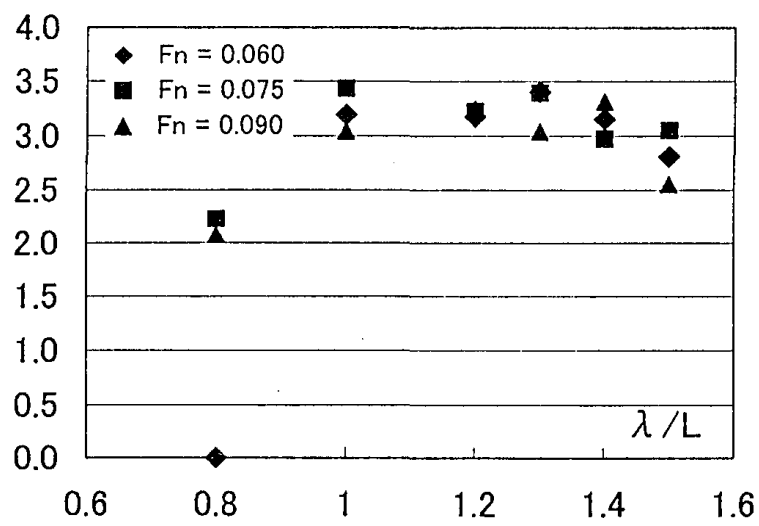

図 3 波長船長比による空ガラス高さでの無次元水 流上昇速度の変化

$(H / \lambda \fallingdotseq 1 / 10)$ 


\section{5. 議 論}

本実験のように波岨度が高い正面向波中では船首部分から打ち込んだ水が甲板上船体中心線上で収束現 象を生じ、この収束流が高速で船橋前端面に衝突した後に方向を変えて上方に駆け昇る現象が観察された。 これらの現象は、中央及び船尾船橋船には生じないので従来余り重要視されていないが、本論で対象とし た船首船橋船にとっては安全操船・安全設計上から調査研究が必要であると考える。ただし今研究では現 象の抽出と指摘を主としたので実用及び設計への具体的考慮は以後の課題として、ここでは船首甲板上打 ち込み水の流動の収束性と船橋前端面を駆け昇った水流の流速について若干議論する。

5.1 打ち込み水の流動の収束性

今回の実験では船首側部から打ち込んだ横方向成分の流れが収束流を引き起こしている。Buchner ${ }^{(1)}$ FPSO (Floating Production Storage and Offloading)船型の模型実験により船体中心線上での流机の収 束性を指摘している。また船首水面上形状や甲板面積等の差異によって打ち込み水の様子と流動模様が違 うことが指摘されているので(2)(3)(4)、条件によっては流㞦の収束が起こることは了解できる。今回の実験 で、この流れの収束が顕著に現れた場合、これは船首船橋船にとって危険な事態になり得ることが判った ので今後流水の収束性に及ぼす種々の影響について検討する必要がある。

\section{2 船橋前面の上昇水流}

高速水流の上昇仰角は甲板上に打ち込んだ水の量、船体中心線上での収束程度及び流速に関係があり、 多量の水が高速で収束する場合に上の現象が明瞭となる。しかしこれら条件の定量的な検討は将来の課題 として、ここでは観察から得られた知見を少し記す。

写真 3 に見られるような上昇水流は上記の条件を満たしている場合であり、水流は直線的に上昇するが、 例えば $\lambda / L=1.5$ の場合は上昇水流の様子が少し異なり、船橋各層の甲板暴露部の凹凸にやや従った流れ 模様となる。このような場合、空ガラスへの水流の衝突角度は写真 3 のものと異なるかも知れない。

水流の上昇速度は元の甲板上の流動速度に依存しているので、この速度について他と比較して一般的な 議論をするのが順序であるが、これについても今後の課題としたい。

\section{6. おわりに}

船首船橋船の模型実験を行って以下の結果を得た。

（1）荒天正面向波中、船首甲板上に打ち込んだ水は船体中心線上で収束現象を起こし、大量の水が高速で 後方に流れることがわかった。

(2) 多量の収束流が発生する場合には船橋前端面に衝突した後、この面をかけ昇って操舵室前面空を越え る高速水流が生じることがわかった。

（3）高速水流の上昇仰角は必ずしも船橋最前端面の勾配に一致せず、むしろ船橋楼甲板等の前端部を結ん だ角度で上昇して船橋空スに直撃することがわかった。

(4) 空ガラスを越える高速上昇水流は波岨度 $1 / 15$ では発生せず、波岨度 $1 / 10$ 程度になると顕著となり、こ の時波高船長比 1.0 以上で公ガラス位置での上昇速度は波面の最大上昇速度の $3.0 \sim 3.5$ 倍にになること がわかった。

今回の研究は、船橋空ガラスにまで達する打ち込み海水の挙動について主に現象的な確認を目的に害施

した。 5 .議論でも述べたような課題があるので、今後設計や操船を考慮した研究を進める予定である。 最後に、本研究の実施に当たって大阪大学戸田保幸助教授 (研究当時神戸商船大学) に映像記録関係で積 極的な支援をいただきました。また実験に当たっては当時の船舶工学研究室の大学院生と 4 年生から多大 な協力を得ることができました。ここに記して謝意とします。

\section{参 考 文 献}

(1) B. Buchner : On the Impact of Green Water Loading on Ship and Offshore Unit Design, PRADS' 95, pp.1.430-1.443, 1995.

(2) Lloyd, A. R. J. M., Salsich, J, O. and Zseleczky, J. J. : The Effect of Bow Shape on deck Wet- 
ness in Head Seas, Transaction R. I. N. A., Vol. 128, pp.9-25, 1986.

（3）高木健・内藤林：海水打ち込みと船首形状の影響について，関西造船協会誌第220号，pp.111-120, 1993.

(4) 溝口純敏：デッキ打ち込み水の挙動について，日本造船学会論文集163号，pp.150-159，1988.

\section{質 疑 応 答}

岩本才次 (九州大学)：打ち込み水の挙動に関する貴重な害験結果をお示しいただき有り難うございます。 次の 2 点をお伺いします。

（1）船首船橋をかけ昇る水流の上昇仰角は船橋前端の傾斜角ではなく、船橋楼各甲板の前端部を結んだ 線に沿って上昇するということですが、そのしくみは流体力学的にどのように考えたらよいのでしょう か。

（2）操舵室前面空ガラスに達した打ち込み水の実験結果の速度は、実船に換算すると実際の空ガラスを 破壊するような流速に達するものだったのでしょうか。

定兼廣行：御討論有り難うございます。

（1）流体力学的につめた考虑はまだ現在十分できていません。観察によりますと、収束する水の量と流 速によって上昇水流の流動模様が変わり、水量、流速が大きいときにご質問の水流となるようです。

（2）今回大略の流速が解析できた段階です。空ガラスの破壊については水流の衝突圧力の推定、ガラス 強度等について検討する必要があり、今後研究を進めていく予定にしています。ただし概算では、破壊 に至り得るとの感触を持っています。 